\title{
Health impact of river water pollution in Malaysia
}

\author{
Rafia Afroz ${ }^{1, *}$, Ataur Rahman ${ }^{2}$ \\ ${ }^{1}$ Department of Economics, Faculty of Economics and Management Science, International Islamic University Malaysia, Selangor, \\ Malaysia \\ ${ }^{2}$ Department of Mechanical Engineering, Faculty of Engineering, International Islamic University Malaysia, Selangor, Malaysia
}

\section{A R T I C LE IN F O}

\section{Article history:}

Received 13 January 2017

Received in revised form

24 March 2017

Accepted 26 March 2017

\section{Keywords:}

River water pollution

Health impact

River water quality

\begin{abstract}
A B S T R A C T
Water pollution is a severe problem in Malaysia and has an adverse impact on the sustainability of water resources. Not only has that but also affected plants and living organisms, the health of the population and the economy. This study reviews the state of river water quality and sources of river water pollution in Malaysia. The Department of Environment program continued monitoring of the quality of river water in 2014 to determine the status of water quality of the river and to detect changes in water quality of the river. They found that $52 \%$ of the river was found to be clean, $39 \%$ slightly contaminated and $9 \%$ contaminated. The number of the polluted river is declined over the period of time. They also observed that beverage industries are the major source of pollution in this country. This paper reviews the environmental policy related to water pollution and studies related to water pollution and health impacts.
\end{abstract}

(C) 2017 The Authors. Published by IASE. This is an open access article under the CC BY-NC-ND license (http://creativecommons.org/licenses/by-nc-nd/4.0/).

\section{Introduction}

Water pollution is a serious problem in Malaysia and has an adverse impact on the sustainability of water resources. Not only that, but it also affects living plants and organisms, the health of the population and the economy. The total availability of water significantly as the cost of treatment of contaminated water is too high and in some cases, polluted water is not susceptible to consumption is reduced. A lot of water resources available in the basin, unfortunately, do not guarantee an adequate supply to all users due to river pollution (Ling, 2010). Development in our watersheds leads to an increase in population activities and urban life. The effect of urbanization typically changes the quality of runoff in a basin, which in turn affects the water quality of the receiving waters. Rainfall in urban areas washes pollutants accumulated on the surface of the ground in rainwater facilities. Wastewater from residential, commercial and industrial zones causes a bad odor, especially in the presence of trash, and quality deteriorates existing rainwater systems and contaminated rivers. Most sources of pollution have been caused by human activity, although some come from natural sources of

\footnotetext{
* Corresponding Author.

Email Address: rafia@iium.edu.my (R. Afroz)

https://doi.org/10.21833/ijaas.2017.05.014

2313-626X/@ 2017 The Authors. Published by IASE.

This is an open access article under the CC BY-NC-ND license

(http://creativecommons.org/licenses/by-nc-nd/4.0/)
}

contamination. The problem of water pollution is becoming increasingly dangerous, with reports showing a downward trend year after year. However, water pollution is not a recent environmental issue, as it has been synonymous with urbanization and modernization. Malaysia's primary fresh water source, accounting for about $97 \%$ of the total water supply (Gasim et al., 2009). Malaysia is well endowed with copious amounts of water and water resources. With an average precipitation of $3,000 \mathrm{~mm}$, it is estimated that 566 billion $\mathrm{m} 3$ of water run in the river system each year (Weng, 2005).

\section{River water quality classification}

There are mainly two main methods used to classify the water quality of the monitored river. First, the Water Quality Index (WQA), and secondly, the National Interim Water Quality Standard (INWQS). The INWQS defines six categories (I, IIA, IIB, III, IV and V) referring to the classification based on descending order of water quality of the rivers of Class I and Class V is "worse." Table 1 shows the class definition provided by INWQS.

On the other hand, six parameters were chosen for the WQI, such as dissolved oxygen (DO), biochemical oxygen demand (BOD), chemical oxygen demand (COD), suspended solids (SS) The ammoniacal nitrogen (NH3-N) PH. Calculations are performed not on the same parameters, but on their subscripts. The subscripts are called BEEN, SIBOD, 
SICOD, SIAN, SISS, and SIPH. The best Fit equations used to estimate the six index values below Table 2 .

The DOE (2014) program continued to monitor river water quality in 2014 to determine the state of river water quality and detect changes in river water quality. Water samples were collected at regular intervals at designated in situ stations and laboratory tests to determine the biological and physicochemical characteristics. The WQI is used to indicate the level of pollution and water classes and corresponding methods compared to the Malaysian National Water Quality Standards (ANEQ) (ANNEX).

Table 1: INWQS class definitions

\begin{tabular}{cl}
\hline Class & \multicolumn{1}{c}{ Definition } \\
\hline I & $\begin{array}{l}\text { - Conservation of natural environment. } \\
\text { - Water supply I - Practically no treatment necessary (except by disinfection or boiling only). } \\
\text { - Fishery I - Very sensitive aquatic species. }\end{array}$ \\
IIA & $\begin{array}{l}\text { - Water supply II - Conventional treatment required. } \\
\text { - Fishery II - Sensitive aquatic species. }\end{array}$ \\
IIB & Recreational use with body contact. \\
III & $\begin{array}{l}\text { - Water supply III - Extensive treatment required. } \\
\text { IV }\end{array}$ \\
V & $\begin{array}{l}\text { Irrigation } \\
\text { None of the above. }\end{array}$
\end{tabular}

Table 2: DOE water quality classification based on water quality index

\begin{tabular}{cccc}
\hline Parameters & \multicolumn{3}{c}{ Index range } \\
\hline & Clean & Slightly polluted & Polluted \\
\cline { 2 - 4 } SIBOD & $91-100$ & $80-90$ & $0-79$ \\
SIAN & $92-100$ & $71-91$ & $0-70$ \\
SISS & $76-100$ & $70-75$ & $0-69$ \\
WQI & $81-100$ & $60-80$ & $0-59$ \\
\hline \multicolumn{4}{c}{ Source: Zainudin $(2010)$}
\end{tabular}

ICA takes into account parameters such as DO, BOD, COD, NH3-N), SS, and pH. In 2014, the water quality of the rivers was evaluated in a total of 6,076 samples taken from a total of 891 manuals of monitoring stations that cover 477 streams. The plants consist of 801 stations and environmental baseline, 55 upstream of selected water intakes, and 35 stations for the River Life Project (RLP). Water quality was also evaluated from 10 monitoring stations of continuous water quality.

\section{State of the river water quality}

Of the 473 rivers monitored, 244 (52\%) were clean, 186 (39\%) were slightly contaminated, and 43 (9\%) were infected (Fig. 1). As in previous years, BOD, NH3-N, and SS continued to be significant regarding river pollution. High BOD can be attributed to inadequate treatment of sewage or effluent from the agriculture and manufacturing industries.

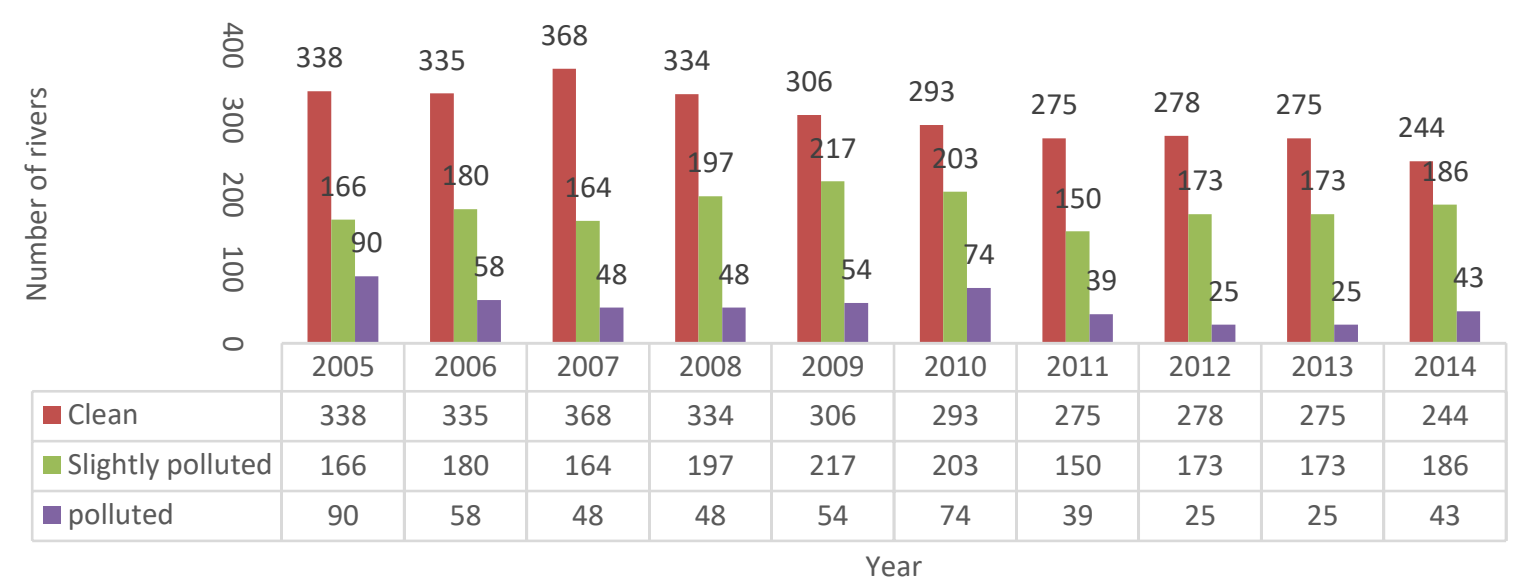

Fig. 1: River water quality trend in Malaysia

The primary sources of NH3-N were livestock and domestic wastewater. From the formulated WQI, total contaminated rivers (including the slightly contaminated Class III River) are declining by $10 \%$ of all streams monitored in 2007, approximately 5\% in 2011. At a glance in Fig. 2, the WQI data Show a decrease in the number of contaminated rivers.

However, when we focus on BOD-based river classes (Table 3), we find that contaminated rivers (class III and IV) are rising $34.6 \%$ (in 2010) to $89.3 \%$ 
(in 2014) of the total monitored river. Table 3 shows the percentage of the polluted river as reported by DOE Malaysia between 2010-2014 based on water quality index, biological oxygen demand (BOD), suspended solid (SS) and ammoniacal nitrogen (AN).

Depending on the results of monitoring by the DOE in 2012, regarding the river basin formed, the Klang River Basin received the highest BOD load (142 tons per day). The Klang River basin also received the highest SS load (360 tons per day) and the NH3-N load (37 tons per day) between the Malaysian watersheds.

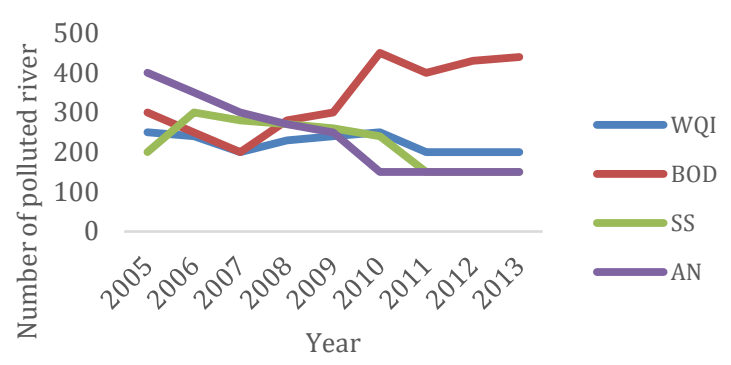

Fig. 2: Number of the polluted rivers as reported by DOE based on WQI, BOD, SS and ammoniacal nitrogen (AN)

Table 3: Percentage of polluted river

\begin{tabular}{ccccccccc}
\hline & \multicolumn{3}{c}{ Suspended solid } & \multicolumn{2}{c}{ Biochemical oxygen demand } & \multicolumn{2}{c}{ Ammoniacal Nitrogen(NH3-N) } \\
\cline { 2 - 9 } Year & \multirow{2}{*}{ Clean } & $\begin{array}{c}\text { Slightly } \\
\text { Polluted }\end{array}$ & Polluted & Clean & $\begin{array}{c}\text { Slightly } \\
\text { Polluted }\end{array}$ & Polluted & \multirow{2}{*}{ Clean } & $\begin{array}{c}\text { Slightly } \\
\text { Polluted }\end{array}$ \\
\cline { 2 - 9 } & \multicolumn{3}{c}{ Percentage } & & Percentage & & Percentage \\
\hline 2010 & 47.6 & 18.8 & 33.6 & 8.4 & 55.2 & 36.4 & 24.5 & 46.1 \\
2014 & 70.7 & 15.7 & 13.6 & & 10.7 & 89.3 & 29.3 & 42.1 \\
\hline
\end{tabular}

\section{Sources of river water pollution}

Sources of water pollution can be classified into point sources and non-point sources. Point sources refer to sources with discharges that enter the body of water at a particular location such as pipelines or emissaries. Point sources include discharges from industries, sewage treatment plants, and animal farms. Non-point sources are derived from diffuse sources that have no examples of specific release points from which they come from agricultural activities and surface runoff. Table 4 shows the sources of water pollution in Malaysia. In 2014, $1,488,848$ sources of water pollution were identified compared to 1662329 sources of pollution in 2013 . It has been found that there is a decrease in the total number of polluting sources in 2014 compared to 2013. But if you look at the Individual sources of water pollution, there is a significant increase in food services, rubber mill, public and private wastewater treatment plants and wet market.

An analysis of manufacturing industries in 2000 showed that the food and beverage industry accounted for 23.7 percent of total sources of water pollution, while electricity and electronics accounted for 11.4 per cent. The chemical industry contributes $11.2 \%$, and the paper industry generates $8.8 \%$ of the total contamination. The finishing industry/textile accounted for 7.4 and $5.3 \%$ of the sources of water pollution, respectively. Effluents from factories, oil palm, and rubber generated in water resources amounted to 5.3 and 2\%, respectively (Muyibi et al., 2008). In general, Selangor, Johor, and Perak were severely contaminated by these sources of parameters (DOE, 2014).

Table 4: River water pollution sources in Malaysia in 2014

\begin{tabular}{|c|c|c|c|c|c|}
\hline \multirow{2}{*}{ Type of source } & \multicolumn{2}{|c|}{ No of Source } & \multicolumn{2}{|c|}{ Percentage } & \multirow[t]{2}{*}{ Change } \\
\hline & 2013 & 2014 & 2013 & 2014 & \\
\hline Manufacturing industries & 4595 & 3355 & 0.276 & 0.225 & -0.051 \\
\hline \multicolumn{6}{|c|}{ Agro Based industries } \\
\hline Rubber Mill & 72 & 80 & 0.004 & 0.005 & 0.001 \\
\hline Palm Oil Mill & 436 & 451 & 0.026 & 0.0003 & -0.026 \\
\hline Animal Pig & 754 & 755 & 0.045 & & \\
\hline \multicolumn{6}{|c|}{ Sewage Treatment Plant } \\
\hline Public & 5800 & 6201 & 0.349 & 0.416 & 0.068 \\
\hline Private & 4083 & 4594 & 0.246 & 0.3 & 0.054 \\
\hline Individual septic tank & 1449383 & 1276195 & 87.190 & 85.76 & -1.430 \\
\hline Commercial septic tank & 3631 & 3628 & 0.218 & 0.24 & 0.022 \\
\hline Food Services Establishment & 192710 & 192710 & 11.593 & 12.95 & 1.357 \\
\hline \multirow[t]{2}{*}{ Wet Markets } & 865 & 879 & 0.052 & 0.11 & 0.058 \\
\hline & 1662329 & 1488848 & 100 & 100 & \\
\hline
\end{tabular}

\section{Impact of water pollution on health in Malaysia}

Contaminated water consists of discharged industrial effluents, sewage, and rainwater. The use of this type of water is a common practice in agriculture. The estimate indicates that more than 50 countries in the world with an area of 20 million hectares are treated with contaminated or partially contaminated water (Ashraf et al., 2010). In developing countries of the world, more than 80 percent of contaminated water has been used for irrigation with only seventy-eight percent of food and safety in urban and semi-urban industrial areas (Mara and Cairncross, 1989). Contaminated water has both advantages and disadvantages. The uses of contaminated water for the effects of water pollution are numerous. Some effects of water pollution are recognized immediately, while others do not appear for months or years. When toxins are in the water, toxins travel from the water that animals drink to humans when the meat of animals is eaten for 
contaminants to enter the food chain. Infectious diseases such as typhoid fever and cholera can be contracted by drinking contaminated water. This health impact of water pollution is called microbial water pollution. The human heart and kidneys may be adversely affected if they drink contaminated water regularly. Other health problems associated with contaminated water are poor blood circulation, skin lesions, vomiting and damage to the nervous system. In fact, the effects of water pollution are the leading cause of death for humans around the world (Ghafoor et al., 1994). Good health is something everyone wants, for them, their children and for the broader economic and social benefits it brings to society. It plays a significant role in the long-term economic growth and sustainable development. Malaysian society has become increasingly urbanized and more involved. By supporting contemporary lifestyles, air, water, and soil pollution have increased; Persistent chemical pollutants have gradually become generalized and global climate change poses new risks to environmental health. These factors are contributing to communicable diseases, non-communicable diseases, physiological and neurological disorders.

Amirah et al. (2013), is responsible for assessing the risk to human health of metal contamination through the consumption of fish in the selected area in Kuantan, Pahang River. This research describes the analysis of the evaluation experiment on metal and the high risk for health. The inductively coupled plasma membrane system (ICP-MS) was used to determine the concentration of heavy metals in fish. The average concentration of $\mathrm{Cu}, \mathrm{Pb}$, and $\mathrm{Cd}$ at three sites is about $0.0205 \mu \mathrm{g} / \mathrm{g}, 0.0145 \mu \mathrm{g} / \mathrm{g}$ of 0.0004 $\mu \mathrm{g} / \mathrm{g}$. The hazard risk ratio (THQ) was used in the health risk assessment to determine the carcinogenicity of the sample. The result shows that the concentration and THQ around the metal pin IED $(\mathrm{Cu}, \mathrm{Pb}, \mathrm{Cd})$ are less than 1 ; This means that daily exposure at this level is unlikely to cause adverse effects throughout the person's life.

Lonergan and Vansickle (1991) conducted a study on the relationship between water quality and human health. The implicit assumption behind these projects is to improve physical infrastructure, and further improvements in water quality, substantially reduce water-related diseases. This study questions this assumption and uses a socio-ecological model as a framework for assessing risk factors associated with increased likelihood of waterborne diseases. The research focuses on Port Dickson, a district that defines the conditions of existing waters and the mostly semi-rural sanitation of Malaysia. We used health service utilization data and a survey of 268 diarrheal disease households to measure the burden of waterborne diseases in the district's disease and to identify predictors of disease. While treatment facilities will reduce the health burden in the region, some behavioral and sanitation factors may be more important and could act to minimize the potential impacts of improved water quality.
Jamaludin et al. (2013) conducted a study on the health risk assessment of nitrate exposure in residents of the drinking water well area to determine the health hazard of inhabitants in the intensive cultivation zone By Bachok Kelantan. The nitrate in safe water was determined with a spectrophotometer, while the health risk was determined by calculating chronic daily intake (ICD) and the risk index (HI). The results indicate that the nitrate level in this study was below the limit of the maximum National Drinking Water Quality Standards (NDWQS) concentration $(<10 \mathrm{mg} \mathrm{L}-1)$ at the mean \pm standard deviation of $1,66 \pm 2.11 \mathrm{mg} \mathrm{L}-1$ and the range from 0 to $9.60 \mathrm{mg} \mathrm{L}-1$.

A cross-sectional study was conducted by Qaiyum et al. (2011) in Mukim Part Lubok (MPL) and Parit Raja (PR), Batu Pahat, Malaysia determined the concentration of aluminum in drinking water and to predict health. The respondents were from these two residential areas. A total of 100 respondents were selected from the study areas by inclusive and exclusive criteria. Two duplicate samples of treated water were taken from the household of each respondent using $200 \mathrm{ml}$ of high-density polyethylene (HDPE) and $0.4 \mathrm{ml}$ (69\%) of pure concentrated nitric acid as the preservative. The concentrations of aluminum were analyzed using a Lambda $25 \mathrm{UV}$ / V spectrophotometer. The result showed that the concentration of aluminum in MPL drinking water was $0.18 \pm 0.022 \mathrm{mg} / \mathrm{L}$ and $0.22 \pm$ $0.044 \mathrm{mg} / \mathrm{L}$ for PR.

Statistical analysis showed that 14 samples (28\%) of water collected from MPL and 35 (70\%) of an aluminum concentration of PR were recorded above the standard limit established by the Ministry of Health's guide for drinking water $(0,2 \mathrm{mg} / \mathrm{L})$. The mean value of daily chronic aluminum intake (CDI) in PR drinking water $(0.00707 \mathrm{mg} / \mathrm{kg} / \mathrm{day})$ was significantly higher compared to MPL $(0.00164$ $\mathrm{mg} / \mathrm{kg} / \mathrm{day}$ ). The calculation of the risk index (HI) showed that respondents had less than 1 . In conclusion, there was an incredible potential for adverse health effects of aluminum intake in drinking water from the two areas of study. However, it was necessary to take some measures to reduce aluminum levels in drinking water for both places.

When analyzing data on river pollution from 2007-2012, Wahab (2015) found that river pollution has a high correlation with gross domestic product, not in the same year, but in the previous two years. It indicates a time delay. It was also found that underfive infant mortality has a strong correlation with river pollution. The triangular cycle of health development must be put in balance to ensure national prosperity and sustainability of the nation.

Afroz et al. (2016) conducted a survey in Gombak in 2014 to investigate the perceived risk of household water contamination and to examine demographic and socioeconomic factors that influence their perception of risk. Respondents were asked to rate the six specific diseases caused by water pollution in the Gombak River area. The 
results reported that $45.2 \%$ of the interviewees selected diarrhea as the most severe disease in the Gombak River area. To them, diarrhea was much higher than that of other types of diseases. $13.3 \%$ of respondents classified dengue fever as the second most dangerous disease. Water pollution causes only $2 \%$ of households classified hair conditions (Figs. 3 and 4).

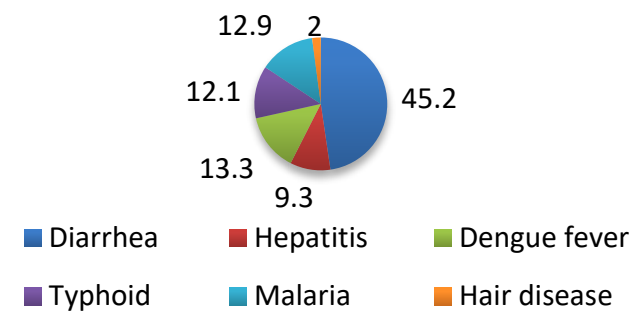

Fig. 3: Disease caused by water pollution

In their study, they asked respondents where they got their drinking water. There were several sources of drinking water. $40 \%$ of respondents who buy for drinking water, city water (30\%), individual well $(16.0 \%)$ and only $5 \%$ respond that they do not know the source of drinking water. During the storage of drinking water also, they did not use any special precaution. About 68\% stored water in plastic buckets, $16 \%$ in earthenware, $10 \%$ in stainless steel containers and $6 \%$ in others as shown in Fig. 5. The findings show that $58.9 \%$ of children aged 0-12 years are more affected by diarrhea despite demonstrating only a small fraction of the population.

Most of them did not use any separate glass to draw water from the containers in which the water was stored. Villagers, especially children, did not use basic hygiene measures such as washing their hands before removing water from the storage container. Most villagers reported that they wash their water storage utensil once a month, while some washes it once every 2 to 3 months. Most of them were unaware of some precautions to be taken before and after storing water and preventing waterborne diseases.

On the other hand, those over 60 consider an exaggeratedly small percentage $(2.4 \%)$ of diarrhea, despite apparently having a high vulnerability to diarrhea as shown in Fig. 6. It may occur due to a various treatment depending on the traditional medicine.

It may be attributable to statements made by several respondents, who are confident that they have developed a form of "immunity" to diarrhea disease through an extended connotation with diarrhea and untreated, unboiled water.

The results of their study also indicate that gender, age, education, income, awareness, and attitude have a significant impact on the perception of the risk of water pollution in households. Although it has been shown that water quality influences rates of health problems, the impact of programs to improve water quality can only be minimal since it only affects the primary source. Therefore, there is an urgent need to develop parallel programs to accompany water improvement projects.

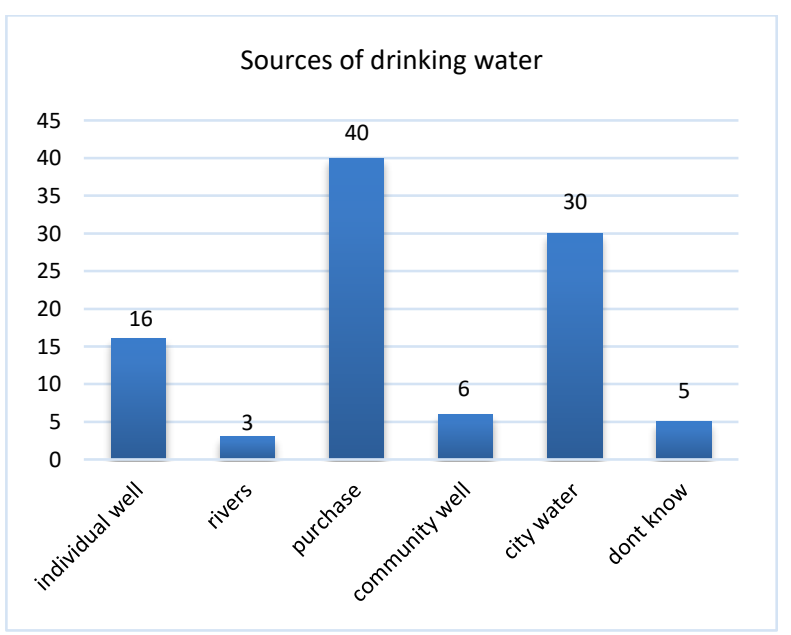

Fig. 4: Source of drinking water

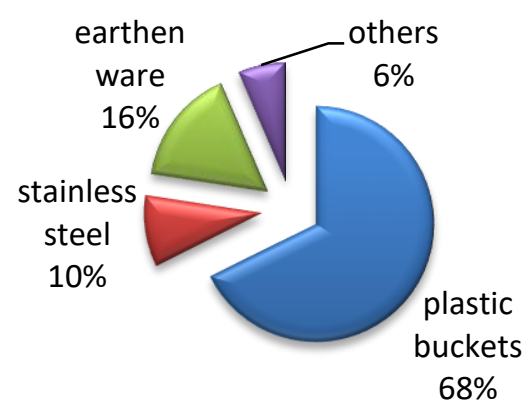

Fig. 5: Storage of drinking water

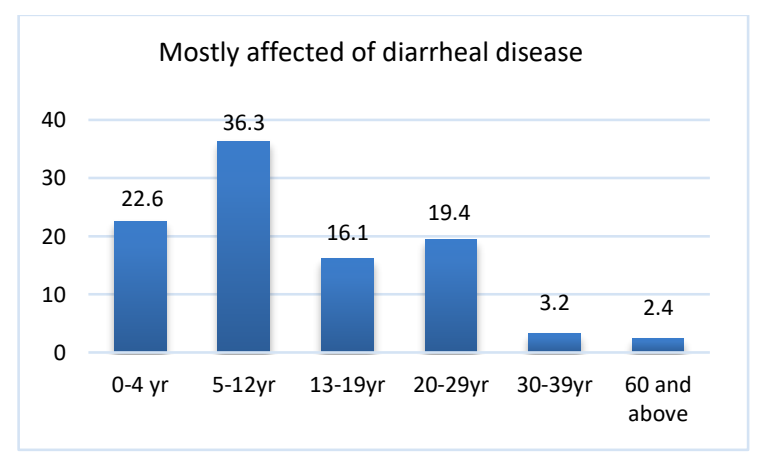

Fig. 6: Mostly affected by diarrhea disease

\section{Water resource policies in Malaysia}

There are several strategies to combat the problems of water quality at international, national and local level.

In order to obtain water quality, there are four key strategies to combat the problems of water quality that can form the basis of policy solutions to improve water quality (Dabelko and Aaron, 2004), such as prevention pollution, treatment of contaminated water, the safe use of wastewater and the restoration and protection of ecosystems. In this section, we discuss the policies of water resources in Malaysia as follows: 


\subsection{National policy}

The National Environmental Policy states that the nation must implement environmentally sound and sustainable economic, social and cultural development progress and improve the quality of life of Malaysians (Daud, 2009) development. It is based on eight inter-related principles of mutual support and respect to water will include the sustainable use of water resources, preservation of the vitality and diversity of a river, and the continuous improvement of water quality. The policy outlines strategies and actions to be taken towards effective management of water resources, pollution control, and prevention of environmental degradation. A holistic approach is needed to manage our water quality of the river.

\subsection{Environmental policy in Malaysia to control river water pollution}

Malaysia has been pollution-related legislation from the 1920s through the Water Act 1920. The main objective of the legislation was to control river pollution. However, the legislation was limited in scope and insufficient to handle the complex environmental problems that emerged. This led to the creation of the Environmental Quality Act (EQA) in 1974 for a more comprehensive form of legislation and an agency to control water pollution (Wichelman, 1976). Importantly, the Act was designed as a framework for other laws and regulations or ordinances which were enacted after it. EQA is a piece that allows the legislation to prevent, reduce and control pollution and improving environmental resources in general. Pollution, as stated in EQA, including direct or indirect alteration of any quality of the environment or any part of it through positive act or act of broadcasting. Pollution control was through the mechanism of the license issued by the Department of Environment (DOE).

The control mode includes prescribing licenses that were mandatory for prescribed use and occupancy of premises; discharge or emission of residues exceeding acceptable conditions to the atmosphere causing pollution or contamination of any type of soil or any land surface; and discharge or deposit any waste or oil above the acceptable conditions in Malaysian waters inland. Currently about 16 of the 43 sets of regulations and orders to avoid damage to the environment, they are particularly pollution of various kinds and executed by the DOE under the EQA. One of the three strategies incorporated in EQA was the regulation of pollution. The other two strategies were to prevent and reduce all forms of pollution, especially water pollution. Overall, the pace of EQA marked a new chapter in national efforts to improve the quality of the environment conducive to a life of the population. He also represented a new focus on prevention, reduction, and control of water pollution. A detailed analysis of the provisions of Article 25 of EQA shows that Malaysia's approach to environmental pollution management is broad in scope and not in relation to pollution itself, but with the pollution affecting the beneficial use of water resources examination. Beneficial use involves the use of any element or segment of the environment that is conducive to public health, welfare or safety requires protection against the effects of waste discharges, emissions, and deposits in rivers. The general scheme Section $25 \mathrm{EQA}$, in relation to the preservation of the environment, leans more towards controlling water pollution. This should be done through licensing by the DOE. EQA authorizes the relevant minister to prescribe the level of acceptable conditions, although it may involve some contentious arguments between affected and polluters. To achieve the objectives of control water pollution in the country as outlined in EQA, laws/orders and regulations relating to the control of an agro-based episode of water pollution were enacted chronologically. An indirect measure to prevent water pollution was Street, Drainage and Building Act enacted in 1974. Section 70A of the Act dealt with the basic requirement for earthmoving to ensure protection from pollution of water resources. They could awaken the earthworks. In this regard, local authorities were entitled to use their discretion to reject any activity that may create soil erosion and sedimentation of water resources. There were several other provisions of this Act authorizing local authorities to control and prevent pollution of inland waters. This was most pronounced in section $7 \mathrm{~A}$ of the Act 1976.The Local Government Act contains provisions on pollution reduction in overall control, but water pollution in particular. Local authorities were empowered to curb disorderly conduct to ensure that the source of drinking water supplies is not contaminated. Another regulatory policy for the protection of inland waters is Street, Drainage and Building Act 1974 (McCourt, 2008). This Act is a federal law enacted to amend and consolidate the laws relating to drainage and construction areas local authorities, with particular reference to the infra- structure facilities to be provided to buildings, such as adequate access to modern sanitation system and proper drainage system can also protect pollution.

In water, it requires the Local authority to properly maintain clear, emptying sewers, drains, and waterways in your area. You can also empty the sewage in the sea areas or other adjustment or transmitted throug16h own channel in the most convenient dump. The local authority can use its discretion to reject any activity that may result in water pollution or soil erosion and sedimentation of the watercourse. The Town and Country Planning Act 1976 have also been formulated to include a provision for the prevention of environmental pollution. Although it is not ready directly to water pollution, provides for the development and use of land and measures to improve the physical environment. The inclusion of environmental and social dimensions of well-being in the process of planning in the Act indicates that the planning process is not simply focused on the built and 
natural environment, but takes into account the social implications and the public view of development. In this sense, planning is central to the notion of a balance between development and environmental ethos protection of natural resources. It ensures that development projects do not cause damage to water resources or to ensure that development projects and factories and is adjacent to the river and in close proximity to rivers. Under the Act 3 of 1970, the Malaysian government has formulated the Land Conservation to protect some of the major contributors of pollution of inland waters, such as sedimentation and soil erosion. In view of the fact that the nature of the discharge of sediment and erosion leading to water pollution are from nonpoint sources such as activities involving earthmoving operations, logging and land clearing a regulatory policy were enacted at the state and federal levels Malaysia. Following the Federal Regulation, many control enactments have been adopted under the competence of the state authority. Other Acts and Regulations include: (Licensing) Regulations of Environmental Quality, 1977; Environmental Quality (Local prescribed) crude palm oil Order, 1977 and its amendment in 1982; Environmental Quality (prescribed Premises) Order relating to Raw Natural Rubber, 1978 Environmental Quality (prescribed Premises) Regulations related raw Natural Rubber, 1978 Environmental Audit (EA) and Environmental Impact Assessment (EIA). With respect to control municipal and industrial wastewater pollution, environmental quality related to sewage and industrial effluent regulation was enacted in 1979. In fact, control of industrial emissions caused a concern for the government. To update this, Mahathir administration in 1981 enacted the Environmental Management Control hazardous waste.

Environmental quality standards related to waste programmed was approved in 1989. In order to take action, Orders and Environmental Quality Regulation (prescribed premises) related to waste treatment and disposal facilities are scheduled simultaneously introduced in 1989. In 1990, Investment Promotion Order (made under the Investment Promotion Act in 1986) was enacted to regulate environmental issues in the context of investment activities that may affect any environmental resource, particular water. This was then followed by the Prohibition of Use of Controlled Substance in soap, synthetic detergents, and other cleaning products Order approved in 1995. These were strictly emphasized in the EIA in 1987.

\section{Conclusion}

Water pollution is a serious problem in Malaysia and has an adverse impact on the sustainability of water resources. Not only that, but it also affects living plants and organisms, the health of the population and the economy. The total availability of water significantly as the cost of treatment of contaminated water is too high and in some cases, polluted water is not susceptible to consumption is reduced. Muyibi et al. (2008) showed that development regarding industrialization, urbanization and population growth explains several changes in the annual level of pollution in Malaysian rivers. As such, water pollution trends tend to be sporadic in nature to the present situation, despite all policy measures and actions were taken by DOE, as well as technologies for waste treatment. The document has considered technology and policy measures as moderating the balance between development activities and water pollution. The findings of his study have also pointed to many implications for lawmakers. First, the outcome of the interactive effects of predictors on contaminated water implies that policy measures that could be taken against individual sources of water pollution would be ineffective when actions were concentrated to control only one source of water contamination. In other words, it implies that copolicy instruments and effects must be very strict; working together against all identified sources of water pollutants. Secondly, policy measures against water pollution may be appropriate and effective, but the lack of coordination actions and holistic actions in policy implementation could lead to a failure to improve the level of river pollution in the country. Third, the problem may also be associated in part with financial constraints to invest in appropriate technology, especially sewer systems to control the human source of water pollution in the country. In the case of waste treatment, most technologies currently rely only on primary and secondary treatments. Since Tertiary or Advanced Treatment is not used in the country, it, therefore, implies that the effluent from such treatment plants will be very high in nutrient loads. Fourth, the problem could be associated with a lack of cooperation between government and private companies to comply with water pollution regulatory policies. Fifth, the availability of technologies in industries does not require a reduction of water pollution, but depends on the adequacy of these techniques regarding capacity and dates; and the conformity of industries interested firms to install these technologies. Also, most of these technologies are only capable of primary and secondary operations. Advanced and tertiary waste treatment operations are needed to reduce water pollution. Sixth another central point of the problem is the issue of the license policy of infringement awarded to some film industries as well as their renewals.

Finally, personal awareness is one of the most important recommendations to protect water from pollution. Therefore, an individual should not use any products that are harmful to the environment. They urge stores to abandon the packaging and use of biodegradable materials. In addition, the authority must provide adequate sewerage and drainage systems, as well as formulate strict pollution control standards and educate the people of this city to develop ecological awareness. In addition, an 
awareness campaign is needed to change attitudes, behaviors, and expectations of the public. Furthermore, participation in partnerships is necessary for the contribution and support of local and national groups working to resolve environmental problems at institutional, national and international levels. Each person should have enough information, participate in public hearings, serve on advisory committees, and go to review boards.

\section{References}

Afroz R, Banna H, Masud, MM, Akhtar R, and Yahaya SR (2016). Household's perception of water pollution and its economic impact on human health in Malaysia. Desalination and Water Treatment, 57(1): 115-123.

Amirah MN, Afiza AS, Faizal WIW, Nurliyana MH, and Laili S (2013). Human health risk assessment of metal contamination through consumption of fish. Journal of Environment Pollution and Human Health, 1(1): 1-5.

Ashraf MA, Maah MJ, Yusoff I, and Mehmood K (2010). Effects of polluted water irrigation on environment and health of people in Jabber, District Kasur, Pakistan. International Journal of Basic and Applied Sciences, 10(3): 37-57.

Dabelko D and Aaron T (2004). Water, conflict, and cooperation. Environmental Change and Security Project Report, 10: 60-66.

Daud H (2009). Legislative approach to water quality management in Malaysia: Success and challenges. Department of Environment, Ministry of Natural Resources and Environment, Kuala Lumpur, Malaysia. Available online at: www.doe.gov.my

DOE (2014). The study on pollution prevention and water quality improvement of Sg. Department of Environment Malaysia, Government of Malaysia, Ministry of Natural Resources and Environment, Melaka, Malaysia. Available online at: www.doe.gov.my

Gasim MB, Ismail Sahid ET, Pereira JJ, Mokhtar M, and Abdullah MP (2009). Integrated water resource management and pollution sources in Cameron Highlands, Pahang, Malaysia. American-Eurasian Journal of Agricultural and Environmental Science, 5(6): 725-732.

Ghafoor A, Rauf A, Arif M, and Muzaffar W (1994). Chemical composition of effluents from different industries of the
Faisalabad city. Pakistan Journal of Agricultural Sciences, 31(4): 367-370.

Jamaludin N, Sham SM, and Ismail SNS (2013). Health risk assessment of nitrate exposure in the well water of residents in the intensive agriculture area. American Journal of Applied Sciences, 10(5): 442-448.

Ling JKB (2010). Water quality study and its relationship with high tide and low tide at Kuantan river. Ph.D. Dissertation, University Malaysia Pahang, Pahang, Malaysia.

Lonergan S and Vansickle T (1991). Relationship between water quality and human health: A case study of the Linggi River basin in Malaysia. Social Science and Medicine, 33(8): $937-$ 946.

Mara DD and Cairncross S (1989). Guidelines for the safe use of wastewater and excreta in agriculture and aquaculture: Measures for public health protection. World Health Organization, Geneva, Switzerland.

McCourt W (2008). Public management in developing countries: From downsizing to governance. Public Management Review, 10(4): 467-479.

Muyibi SA, Ambali AR, and Eissa GS (2008). The impact of economic development on water pollution: Trends and policy actions in Malaysia. Water Resources Management, 22(4): 485-508.

Qaiyum MS, Shaharudin MS, Syazwan AI, and Muhaimin A (2011). Health risk assessment after exposure to aluminum in drinking water between two different villages. Journal of Water Resource and Protection, 3(4): 268-274.

Wahab MAA (2015). River pollution relationship to the national health indicated by under-five child mortality rate: A case study in Malaysia. Bioremediation Science and Technology Research, 3(1): 20-25.

Weng CN (2005). Sustainable management of rivers in Malaysia: Involving all stakeholders. International Journal of River Basin Management, 3(3): 147-162.

Wichelman AF (1976). Administrative agency implementation of the National Environmental Policy Act of 1969: A conceptual framework for explaining differential response. Natural Resources Journal, 16: 263-300.

Zainudin Z (2010). Benchmarking river water quality in Malaysia. Jurutera: 12-15. Available online at: http://irep.iium.edu.my/ 2954/1/Feature-BenchmarkingRiverWater3pp.pdf 